\title{
Penguatan Gender dalam Pengambilan Keputusan Birokrasi di Kabupaten Bone Bolango
}

Robby Hunawa

Program Studi Ilmu Pemerintahan, Universitas Gorontalo obbyhu@gmail.com

\begin{abstract}
The long-term goal of this research is the birth of the process of drawing women's involvement in the bureaucratic decision-making process, and the gender reinforcement model in bureaucratic decision making in Bone Bolango District. The target of the research will be done by stages: 1) identify the problem of constraints faced; and 2) to formulate a model of gender reinforcement in bureaucratic decision making. The research method used is qualitative research with data collection techniques through: interview, documentation, and FGD. Further data collected will be analyzed data triangulation. The result of the research is the birth of a model of gender reinforcement in decision making bureaucracy. The impact of the study will provide answers on women's partisifasi in decision making. During this time the existence of women is very much ruled out. The presence of female figures in the public dimension brings new trends in the context of government. Women want to be treated proportionally. This tendency has implications for the inclusion of women to compete with men to become leaders.
\end{abstract}

Keywords: gender; decission making; Bone Bolango.

\begin{abstract}
Tujuan jangka panjang dari penelitian ini adalah melahirkan keterlibatan perempuan dalam proses pengambilan keputusan birokrasi, dan model penguatan gender dalam pembuatan keputusan birokrasi di Kabupaten Bone Bolango. Target penelitian akan dilakukan secara bertahap: 1) mengidentifikasi masalah kendala yang dihadapi; dan 2) untuk merumuskan model penguatan gender dalam pengambilan keputusan birokrasi. Metode penelitian yang digunakan adalah penelitian kualitatif dengan teknik pengumpulan data melalui: wawancara, dokumentasi, dan FGD. Data lebih lanjut yang terkumpul akan dianalisis triangulasi data. Hasil dari penelitian ini adalah lahirnya model penguatan gender dalam pengambilan keputusan birokrasi. Dampak penelitian akan memberikan jawaban pada perempuan partisifasi dalam pengambilan keputusan. Selama ini keberadaan perempuan sangat dikesampingkan. Kehadiran tokoh perempuan dalam dimensi publik membawa tren baru dalam konteks pemerintahan. Wanita ingin diperlakukan secara proporsional. Kecenderungan ini berimplikasi pada masuknya perempuan untuk bersaing dengan laki-laki untuk menjadi pemimpin.
\end{abstract}

Kata Kunci: gender; pengambilan keputusan; Bone Bolango. 


\section{PENDAHULUAN}

Keberadaan laki-laki dan perempuan merupakan sebuah keniscayaan, dengan alat tubuh dan berbagai sifat yang melekat dari keduanya menyebabkan secara alamia akan terbentuk kewajiban kodrati yang harus dilakukan laki-laki dan perempuan. Masalah gender menjadi urgen untuk dibahas karena dampaknya pada ketidakadilan sosial yang menimpa perempuan. Dalam konteks masyarakat yang menganut sistem sosial dan budaya patriarkhi, kaum perempuan tidak mendapat hak-hak yang selayaknya. Hal ini juga terjadi dalam birokrasi terutama dalam pnentuan kebijakan. Jabatan struktural yang dikuasai oleh laki-laki jelas berdampak pula pada kebijakan yang dihasilkannya. Birokrasi pemerintahan di Indonesia bertujuan untuk memberikan pelayanan kepada publik sesuai dengan misi yang diberikan kepadanya dari kebijakan-kebijakan publik. Sedangkan pengaruh keutamaan gender merupakan salah satu strategi pembangunan yang dilakukan untuk mencapai kesetaraan dan keadilan gender, melalui pengintegrasian pengalaman, aspirasi, kebutuhan, dan permasalahan perempuan dan laki laki ke dalam perencanaan, pelaksanaan, pemantauan, dan evaluasi dari seluruh kebijakan, program, proyek dan kegiatan di berbagai bidang kehidupan dan pembangunan.

Birokrasi memiliki kekuatan yang besar dalam administrasi publik karena organisasi ini berhubungan langsung dengan publik yang dilayani secara keseluruhan. Perempuan bekerja bukanlah merupakan suatu hal yang tabu untuk dilakukan. Keterlibatan perempuan dalam dunia kerja tidak serta merta mengindikasikan bahwa perempuan bekerja hanya untuk mencari nafkah dan mengejar karir. Ada sebab-sebab lain yang membuat perempuan ingin bekerja, khususnya bekerja di organisasi birokrasi. Makna kerja yang paling mendasar selalu dikaitkan dengan kebutuhan ekonomi, seperti: pemenuhan kebutuhan makanan, tempat tinggal, baik untuk individu dan masyarakat, meskipun demikian ditemukan juga adanya makna kerja lain yang lebih bersifat subjektif yang ditawarkan dari suatu pekerjaan seperti prestasi, kehormatan, kontak sosial mendefinisikan makna kerja sebagai penghayatan seseorang dalam pemenuhan kebutuhan ekonomi individual dengan melaksanakan tugas pekerjaan dari satu tahap ke tahap yang lainnya dalam organisasi.

Cara laki-laki yang berkuasa dalam birokrasi dan menerjemahkan program terhadap perempuan rawan salah sasaran. Sebab sudut pandang yang melekat pada laki-laki terhadap perempuan berbeda-beda.Kadar sensivitasnya lebih tipis jika di banding perempuan sebagai pihak yang mengalami. Wajah kepemimpinan laki-laki juga rawan menjadikan perempuan sebagai objek kebijakan. Perempuan hanya dipaksa menjalankan program,tanpa ditanyakan skala prioritas dan kebutuhan. Program yang diciptakan bisa saja asal menyesuaikan alokasi anggaran. Dalam implementasi kebijakan, perempuan selalu dijadikan subjek, sehingga selalu diajak berpartisipasi memberikan masukan. Perempuan juga harus dilibatkan dalam penentuan program yang sesuai dengan kepribadiannya. Pendekatan kebijakan dari atas ke bawah dihilangkan dengan mengajak yang bawah sebagai bagian pengambil kebijakan yang di atas.

Dalam proses pembangunan dan pemberdayaan masyarakat sudah seharusnya mengembangkan setiap daya yang ada melalui upaya-upaya 
pemberdayaan, salah satunya adalah mengoptimalkan potensi kaum perempuan menjadi sebuah energi khususnya dalam proses perumusan kebijakan publik. Sedikitnya ada empat aktor dalam proses perumusan kebijakan publik yakni golongan rasional, golongan teknisi, golongan intermentalis dan golongan reformis. Keterlibatan kaum perempuan dalam perumusan kebijakan publik digolongkan dalam tipe rasionalis. Dengan keterlibatan perempuan diharapkan kebijakan yang dikeluarkan nantinya oleh birokrasi bisa bermanfat bagi semuanya, baik laki-laki maupun perempuan.

\section{KAJIAN TEORI}

\subsection{Kedudukan dan Peran Perempuan}

Dalam Sosiologi, "perempuan sebagai suatu objek studi banyak diabaikan." Hanya di bidang perkawinan dan keluarga dia dilihat keberadaannya. Kedudukan dalam sosiologi, dengan kata lain bersifat tradisional sebagaimana ditegaskan kepadanya oleh masyarakat yang lebih besar, tempat kaum wanita adalah di rumah. Menurut Jane C. Ollenbueger \& Helen A. Moore (2002:1) peran adalah perangkat tingkah yang diharapkan dimiliki oleh orang yang berkedudukan di masyarakat. Menurut Kamus Besar Bahasa Indonesia (1995) peran merupakan aspek dinamis kedudukan, apabila seseorang melaksanakan hak dan kewajibannya sesuai dengan kedudukannya maka dia menjalankan suatu peran. Soerjono Soekanto (1997: 268) Peran yang melekat pada diri seseorang dapat membedakan posisinya dalam pergaulan di masyarakat.

Perempuan adalah warga negara dari suatu bangsa yang mempunyai tugas, kewajiban dan hak dalam berpartisipasi dalam pembangunan. Perempuan sebagai "empu" mempunyai kewajiban untuk berbuat sesuatu demi kesejahteraan bangsa dan menjadi inspirasi penting bagi tumbuhnya transformasi sosial masyarakat secara lebih berbudaya dan manusiawi. Budi Santoso (1996:13) kaum perempuan telah menjadi peredam kejut bagi berbagai kebijakan perubahan sosial dan penyesuai struktural. Mereka tidak pernah dilibatkan dalam proses yang membuat dirinya sengsara. Persoalan perempuan itu muncul setelah dibongkarnya mitos-mitos kultural dan struktural yang dipandang menyudutkan posisi kaum perempuan, ternyata tidak selesai bahkan makin bertambah kompleks. Sekalipun perempuan telah mempunyai peluang untuk berkiprah dalam pembangunan dan dalam dunia kancah politik secara lebih luas, namun pada dimensi-dimensi tertentu masih ditemukan batas-batas dan problem-problem baru termasuk bahwa idiom-idiom pembangunan dan kiprah di ranah publik dan di dunia politik masih diwarnai kekuasaan laki-laki tampaknya pemberian kesempatan kepada perempuan masih "setengah hati."

Inilah yang menyebabkan ketidakberdayaan (powerless) kaum perempuan dalam menghadapi rekayasa sosial. Perempuan banyak yang menjadi korban sosial dan peralihan industri dalam pembangunan kita. Dengan posisi domestik, mitos dan budaya tidak menempatkan perempuan digaris depan. Dengan bahasa lain sektor domestik dianggap tidak lebih penting daripada dimensi publik. Persepsi dan interpretasi inilah yang membuat para aktivis perempuan melakukan gelombang pemberontakan tentang akses pribadinya dalam sektor publik.

Dalam perkembangnya sampai dengan saat ini, masih saja ada masyarakat yang mengikuti pola pemikiran seperti di atas. Perempuan masih diperlakukan sebagai warga negara kelas dua, dibatasi haknya dalam ikut serta mengambil 
keputusan kolektif serta steril dari posisi-posisi strategis dalam masyarakat. Ketika politik dimaknai sebagai kegiatan pengambilan keputusan di ruang publik yang berdampak kepada masyarakat secara keseluruhan, maka asumsi yang menyatakan perempuan tidak boleh turut serta di dalamnya adalah asumsi yang sudah tidak lagi relevan. Dalam kerangka ini, laki-laki dan perempuan sebagai warga negara haruslah dipandang sebagai entitas yang setara (equal) karena apapun yang diputuskan di ranah politik akan berdampak kepada semuanya, baik laki-laki maupun perempuan.

Sebuah survey yang dilakukan oleh National Democratic Institute (NDI) menyatakan bahwa negara-negara yang memperlakukan kesetaraan antara lakilaki dan perempuan memiliki keunggulan-keunggulan antara lain; standar hidup yang tinggi/lebih baik dan angka korupsi yang cenderung lebih rendah; keterlibatan perempuan dalam semua level, baik lokal, regional maupun nasional memiliki dampak positif pada kehidupan sosial ekonomi warganya, keluargakeluarga serta kelompok-kelompok yang kurang beruntung; dalam masa rekonsiliasi dan rekonstruksi pasca perang atau bencana, pelibatan perempuan mempercepat proses-proses yang dilakukan. Hal tersebut dapat dicapai karena adanya semacam pemahaman yang komprehensif yang didapat dari adanya sinergi antara persepsi, formulasi dan implementasi antara laki-laki dan perempuan. Jika selama ini setiap keputusan berasal dari isi kepala para laki-laki, maka dengan terbukanya kesempatan perempuan berperan dalam pengambilan keputusan maka yang muncul adalah counterpart ide, gagasan dan solusi dari pihak perempuan. Bisa jadi hal tersebut menjadi saling melengkapi dengan hal-hal yang telah ada atau malah menciptakan hal-hal baru yang belum pernah ada karena perbedaan persepsi, emosi dan psikologi antara lakilaki dan perempuan. Dapat dinyatakan bahwa perbedaan antara laki-laki dan perempuan di ruang publik/ranah politik justru memperkaya dan memperlengkap wacana dan pendekatan dalam mengambil keputusan.

Dari penelitian Nurland (2002), paling tidak ada 3 hal yang menjadi kendala peran perempuan pada ranah politik di Indonesia. Pertama, faktor budaya Indonesia yang feodal dan patriarki yang mengungkung perempuan untuk beraktualisasi pada ranah-ranah domestik. Secara tradisi, perempuan ditempatkan pada posisi yang kurang menguntungkan yakni hanya berpusat pada aktifitas rumah tangga. Bahkan ada semacam jargon orang tua yang enggan untuk menyekolahkan anak perempuannya karena paling nanti hanya akan diambil istri dan mengurusi rumah tangga saja Hal semacam ini terusmenerus diturunkan pada setiap generasi sehingga menjadi sebuah nilai yang berlaku dalam masyarakat yang menempatkan laki-laki lebih tinggi kedudukannya dibandingkan dengan perempuan.

Kedua, adanya pemahaman masyarakat yang konservatif atas tafsir ajaran agama. Hal ini dapat dilihat dari berbagai dalil atau hukum agama yang memberikan keistimewaan kepada pihak laki-laki. Sungguh pun bahwa dalil dan hukum tersebut sifatnya adalah tafsir, namun proses sosialisasi yang terusmenerus dapat menjadikan hal tersebut sebagai sebuah dogma/hukum yang tak terbantahkan. Padahal jika dikaji secara lebih mendalam maka agama pun sebenarnya memberikan posisi yang sama antara laki-laki dan perempuan, bahkan mereka dianjurkan untuk saling bekerja sama. Ketiga, munculnya hegemoni negara yang masih sangat besar terhadap warga negara yang terlihat dari dukungan atas budaya patriarki dalam segala aspek. Hal ini seperti yang 
ditentang oleh banyak aktivis perempuan mengenai Undang-undang Anti Pornografi dan Pornoaksi yang masih menjadikan tubuh perempuan sebagai obyek dan diskriminatif. Perempuan dianggap sebagai pihak yang paling bersalah atas munculnya kejahatan susila. Dengan demikian, dari kacamata ini perempuanlah yang harus membatasi dirinya dan memperlakukan dirinya secara sopan dan terhormat. Bagi aktivis perempuan hal ini dianggap tidak adil karena negara tidak juga memperlakukan hal yang sama kepada laki-laki. Dengan kata lain, negara masih saja menerapkan diskrimasi susila kepada perempuan dengan mengatur secara mendetail apa-apa yang patut dan boleh dilakukan oleh perempuan.

\subsection{Pengambilan Keputusan}

G. R. Terry dalam Ibnu Syamsi (2008:5) mengemukakan bahwa pengambilan keputusan adalah sebagai pemilihan yang didasarkan criteria tertentu atas dua atau lebi alternative. Claude S. George, Jr menyatakan proses pengambilan keputusan itu dikerjakan oleh kebanakan manajer berupa suatu kesadara, kegiatan pemikiran yang termasuk pertimbangan dan pemilihan diantara sejumlah alternative. Menurut J reason (1990), pengambilan keputusan dapat dianggap sebagai suatu hasil atau keluaran dan proses mental atau koognitif ang membawa pada pemilihan suatu jalur tindakan diantara beberapa alternative ang tersedia. Setiap proses pengambilan keputusan sealu menghasilkan satu pilihan final.

Horold dan Cril O'Donnel mengatakan bahwa pengambilan keputusan adalah pemilihan diantara alternative mengenai suatu cara bertindak aitu inti perencaan. Suatu rencana tidak dapat dikatakan tidak ada jika tidak ada keputusan, suatu sumber yang dapat dipercaya, petunjuk atau reputasi yang lebih dibuat. P. Siagian (2008:56) mendefenisikan pengambilan keputusan merupakan suatu pendekatan sistematis terhadap suatu masalah, pengumpulan fakta dan data, penelitian yang matang atas alternative dan tindakan.

Pengambilan keputusan merupakan salah satu bentuk perbuatan berpikir dan hasi dari suatu perbuatan itu disebut keputusan. Pengambilan keputusan dalam psikologi kognitif difokuskan pada bagaimana seseorang mengabil keputusan. Dalam kajiannya, berbeda dengan pemecahan masalah yang mana ditandai dengan situasi dimana sebuah tujuan ditetapkan dengan jelas dan dimana pencapaian sebuah sasaran diuraikan menjadi subtujuan, yang pada saatnya membantu menjelaskan tindakan yang harus dan kapan diambil.

Menurut suharman, pengambilan keputusan adalah proses memilih atau menentukan berbagai kemungkinan diantara situasi-situasi yang tidak pasti. Pembuatan keputusan terjadi didalam situasi-situasi yang meminta seseorang harus membuat prediksi kedepan, memilih salah satu diantara dua pilihan atau lebih, membuat estimasi (perkiraan) mengenai prekuensi prakiraan yang akan terjadi. Salah satu fungsi berpikir adalah mentepkan keputusan. Keputusan yang diambil seseorang beraneka ragam. Keputusan merupakan hasil berpikir, hasil usaha intelektual, keputusan selalu melibatkan pilihan dari berbagai alternatiF, keputusan selalu melibatkan tindakan nata, walaupun pelaksanaanna boleh ditangguhkan atau dilupakan. 


\subsection{Konsep Birokrasi}

Secara epistemologis istilah birokrasi berasal dari bahasa Yunani "Bureau" yang artinya meja tulis atau tempat bekerjanya para pejabat. Birokrasi adalah tipe dari suatu organisasi yang dimaksudkan sebagai sarana bagi pemerintah untuk melaksanakan pelayanan umum sesuai dengan permintaan masyarakat. Di dalam masyarakat modern, di mana begitu banyak urusan yang terusmenerus dan cenderung tetap, hanya organisasi birokrasi yang mampu menjawabnya. Dalam menjawab/melaksanakan urusan/tugas yang begitu banyak tersebut, anggota-anggota organisasi birokrasi sangat berperan. Dalam beberapa sebutan/istilah birokrasi sendiri diterjemahkan sebagai pemerintah yang anggota-anggotanya disebut aparat birokrasi atau birokrat, bahkan Rianto Nugroho D dalam buku "Kebijaksanaan Publik" menyebut "Birokrasi dalam praktek dijabarkan sebagai Pegawai Negeri Sipil".

Konsep awal yang mendasari gagasan modern tentang birokrasi berasal dari tulisan-tulisan Max Weber, seorang Sosiolog Jerman, yang mengetengahkan ciriciri pokok dari birokrasi sebagai berikut:

1. Birokrasi melaksanakan kegiatan-kegiatan reguler dalam rangka mencapai tujuan organisasi. Dalam mencapai tujuan tersebut dilakukan pembagian tugas dan tugas-tugas tersebut dilaksanakan oleh para ahli sesuai spesialisasinya.

2. Pengorganisasian kantor berdasar prinsip hierarkhi. Dalam prinsip hierarkhi unit yang besar membawahi dan membina beberapa unit kecil. Setiap unit kecil dipimpin oleh seorang pejabat yang diberi hak, wewenang, dan pertanggungjawaban untuk melaksanakan tugas yang dipercayakan kepadanya.

3. Pelaksanaan tugas diatur dengan suatu peraturan formal dan aturan tersebut mencakup tentang keseragaman dalam melaksanakan tugas.

4. Pejabat yang melaksanakan tugas-tugasnya dengan semangat pengabdian yang tinggi.

5. Pekerjaan dalam organisasi birokratis didasarkan pada kompetensi teknis dan dilindungi dari pemutusan kerja secara sepihak. Menganut suatu jenjang karier berdasar senioritas dan prestasi kerja.

Pengalaman menunjukkan bahwa tipe organisasi administratif yang murni berciri birokratis dilihat dari sudut teknis akan mampu mencapai tingkat efisiensi yang tertinggi.

\section{METODE PENELITIAN}

\subsection{Jenis Penelitian}

Dalam menganalisis penguatan gender dalam pengambilan keputusan birokrasi di Kabupaten Bone Bolango, kajian ini menggunakan jenis kajian Kualitatif. Kajian ini adalah kajian deskriptif dengan menggunakan pendekatan kualitatif. Kajian ini menggunakan analisis institusionalisme karena penelitian ini dilakukan pada suatu bagian organisasi pemerintahan. Pierson dan Skocpol (2002:706) menyatakan bahwa analisis institusional digunakan untuk mengkaji segala sesuatu dari proses efek terhadap gerakan sosial, sampai proses politik hukum.

Pendekatan kualitatif ini menurut Sugiyono (2012:9) digunakan untuk mendapatkan data yang mendalam, suatu data yang mengandung makna. Makna adalah data yang sebenarnya, data yang pasti dan merupakan suatu 
nilai dibalik data yang tampak. Oleh karena itu, dalam penelitian kualitatif tidak menekankan pada generalisasi, tetapi lebih menekankan pada makna. Analisis kualitatif menurut Lincoln dalam Norman (2003: 72) adalah penelitian yang menekankan pada proses dan pemaknaan atau realitas sosial yang tidak diuji atau diukur secara ketat dari segi kuantitas atau frekuensi yang ditekankan pada konstruksi realitas sosial, reaksi antara penngkaji dengan yang dkaji dan kendala situasional yang melingkupi sifat sarat dari masalah gender di Kabupaten Bone Bolango. Fokus kajian ini untuk menjelaskan bagaimana gejala sosial dibentuk dan diberi makna, dimana kajian ini menjelaskan secara mendalam perihal akar penyebab yang dapat menimbulkan penguatan gender dalam pengambilan keputusan birokrasi.

\subsection{Lokasi dan waktu}

Kajian ini mengambil lokasi di Kabupaten Bone Bolango. Adapun dilakukan selam dua bulan. Satu bulan pertama untuk mencari data, selanjtnya bulan berikutnya digunakan untuk menganalisis data.

\subsection{Pengumpulan Data dan informasi}

Pengumpualn data dilakukan dengan metode survei dan wawancara langsung dengan informasi. Untuk mendalami permasalahan pada kasus-kasus tertentu akan dilakukan wawancara mendalam kepada informan yang dianggap tahu dan mempu memberikan informasi terkait dengan permasalahn yang diteliti. Adapun sumber data dan informasi, akni dinas pendidikan, dinas kesehatan, dan dinas pekerjaan umum.

Data dan informasi yang dikumpulkan adalah data dan informasi primer dan sekunder. Data dan informasi primer didipatkan dari hasil wawancara dengan responden dan wawancara mendalam dengan informan, sedangkan data dan informasi sekunder didapatkan dari dokumen-dokumen. Pengumpulan data dan informasi akan dilakukan oleh tim peneliti.

\subsection{Jenis dan Sumber Data}

Jenis dan sumber data yang digunakan pada penelitian ini untuk memperoleh informasi dan sumber data yang lebih akurat dilokasi penelitian ada dua yakni:

\subsubsection{Data sekunder}

Data sekunder yang dimaksud adalah data yang diperoleh dari tepat penelitian meliputi data yang dipublikasikan maupun data yang tidak dipublikasikan oleh instansi terkait dengan persoalan yang akan diteliti mengenai penguatan gender dalam pengambilan keputusan birokrasi di Kabupaten Bone Bolango, literature/buku-bukum pers/media elektronik maupun cetak yang dianggap mempunyai keterkaitan dengan pembahasan. Dalam penelitian ini, data yang dikumpulkan bersumber dari data sekunder yang memiliki hubungan dalam kajian ini di Kabupaten Bone Bolango.

\subsubsection{Data primer}

Data primer yang dimaksud adalah data yang diperoleh secara langsung dilapangan dan berbagai informasi yang merupakan mediator dalam memberikan fakta-fakta dan informasi yang dibutuhkan. Data primer didapatkan dari hasil wawancara langsung dengan beberapa unsur yang dapat memberikan infromasi didalam menjawab bagaimana penguatan gender dalam pengambilan keputusan birokrasi di Kabupaten Bone Bolango. 


\subsection{Analisa Data}

Setelah seluruh data terkumpul maka langkah selanjutnya dilakukan analisis data. Analisis data merupakan langkah yang dilakukan setelah pengumpulan data. Menurut Norman (2003:445) kegiatan analisis data kualitatif mencakup pengujian, mengerutkan, mengkategorikan, mengevaluasi, membandingkan, mensintesiskan dan mengkontemplasikan data yang dikode seperti halnya interview data mentah dan data yang direkam. Sesuai dengan kegiatan tersebut, maka secara garis besar analisis data yang dilakukan dalam penelitian ini melalui tahapan penafsiran data, reduksi data, penyusunan data, pemeriksaan keabsahan data, dan Menarik kesimpulan.

\section{HASIL PENELITIAN DAN PEMBAHASAN}

Penguatan gender dalam pengambilan keputusan merupakan suatu hal yang menarik dikaji diKabupaten Bone Bolango. Karena peran gender dalam pengambilan keputusan birokrasi belum memberikan ruang yang luas bagi perempuan. Oleh karena itu kajian ini menarik untuk dikembangkan lebih luas guna mengetahui proses penguatan gender dalam lingkup birokrasi di Kabupaten Bone Bolango.

\subsection{Keterlibatan Perempuan Dalam Proses Pengambilan Keputusan Birokrasi di Kabupaten Bone Bolango}

Pengambilan keputusan menurut Sumartopo (2000:24) adalah suatu proses pemilihan alternatif baik itu berupa manusia, benda, atau tindakan untuk memperbaiki keadaan sesuai dengan kebutuhan. Tindakan yang telah diputuskan dapat digunakan untuk mencegah terjadinya keadaan yang tidak diinginkan atau memperkecil resiko kerugian harus ditanggung bila peristiwa yang sudah dicoba terulang lagi. Prasyarat mutlak yang dimungkinkan dalam mengambil keputusan sangat ditentukan pada akses dan kontrol yang dimilikinya.

Akses dalam pengambilan keputusan adalah bagian dari kondisi-kondisi yang harus dimiliki oleh siapapun. Tidak dimilikinya akses dan kontrol atas pengambilan keputusan oleh perempuan di Kabupaten Bone Bolango menyebabkan perempuan tidak dapat berpartisipasi secara penuh dalam pembangunan dan menikmati manfaatnya dalam birokrasi. Akses dan kontrol atas berbagai sumber daya yang dimiliki oleh dan laki-laki secara adil, merupakan faktor penting dalam mencapai kondisi yang adil dalam menuju keadilan dan kesetaraan gender. Perempuanlah yang memiliki pengalaman, permasalahan, kebutuhan, kepentingan dengan hal-hal yang berkaitan dengan reproduktifnya. Kehilangan akses dan kontrol yang dimiliki kaum perempuan dalam pengambilan keputusan dalam birokrasi mengakibatkan suatu keadaan tersubordinasi sehingga melahirkan ketergantungan yang berlebihan pada kaum laki-laki.

Dalam isu-isu gender, ketergantungan melahirkan keadaaan yang dialami oleh kaum perempuan yang tidak memiliki penguasaan (kontrol) atas sumber daya ekonomi dan pengambilan keputusan. Dalam banyak negara-negara selatan (negara-negara dunia ketiga), ketika pendapatan kaum perempuan (misalnya, dari pertanian atau kerajinan tangan) dirusak, kaum perempuan tergantung secara ekonomi dan tergantung dalam pengambilan keputusan. Keputusan merupakan jawaban atas masalah yang kita hadapi, walaupun 
keputusan tidak selalu merupakan pemecahan dari suatu masalah, bila keputusan tersebut tidak tepat. Situasi dan kondisi yang terus berubah makin menyulitkan perempuan di Kabupaten Bone Bolango dalam mengambil keputusan dalam birokrasi pemerintahan. Dibutuhkan suatu kompetensi yang handal dalam mendorong suatu penguatan dalam melibatkan perempuan secara adil dan merata dengan laki-laki dalam proses perumusan kebijakan pemerintah.

Pengambil keputusan perlu dilakukan secara dinamis atau bahkan futuristik. Setelah membuat perhitungan secara sistematis dan logis, pengambilan keputusan harus mempertimbangkan resiko atau akibat dari suatu pemilihan masalah. Struktur dan sistem dari kerangka pengambilan keputusan sangat tergantung pada: 1) Posisi pengambil keputusan, 2) Kedudukan masalah yang dihadapi dan harus dipecahkan, 3) Situasi dimana pengambil keputusan itu berada, 4) Kondisi pengambil keputusan yang meliputi kemampuan dan kekuatannya untuk mengadapi masalah tersebut, 5) Tujuan yang harus dicapai dari pengambil keputusan tersebut. Proses pengambilan keputusan menurut Miriam Budiardjo (1998:35) menyatakan bahwa suatu proses pemilihan alternatif, baik itu berupa manusia, benda atau tindakan untuk memperbaiki keadaan sesuai dengan kebutuhan. Keputusan adalah menentukan kegiatan apa yang akan dilakukan, kapan dilakukan, dimana dilakukan siapa yang akan melakukan serta bagaimana kegiatan tersebut dilakukan.

Atmosudirdjo (1982:79) menyebutkan proses pengambilan keputusan dilakukan dengan mendudukan diri sebagai pemimpin. karena itu perlu diidentifikasi dan ditelaah masalah yang ada yang dihadapi dalam penguatan gender di Kabupaten Bone Bolango. Pengidentifikasian dan pemilihan serta penilaian terhadap masalah- masalah yang dihadapi dengan mempertimbangkan pengambilan keputusan birokrasi di Kabupaten Bone Bolango yang masih kurang optimalnya peranan perempuan. Oleh karena itu, perlu menelaah situasi dan kondisi yang dihadapi perempuan di Kabupaten Bone Bolango dalam proses pengambilan keputusan yang masih kurang. Menelaah keputusan yang akan diambil mencari alternatif-alternatif sebagai bagian dari tindak lanjut dari keputusan yang diambil dalam birokrasi.

Proses pengambilan keputusan merupakan inti dari suatu kepemimpinan. Oleh karena itu, efektifitas kepemimpinan seseorang dapat diukur melalui kemahirannya dalam mengambil keputusan. Kepemimpinan itu sendiri merupakan kemampuan mempengarhi perilaku orang lain menjadi bawahan seseorang sedemikian rupa sehingga perilaku tersebut menjadi pendorong yang kuat bagi tindakan-tindakan positif demi kepentingan organisasi. Kelangsungan suatu organisasi sangat tergantung pada keputusan pimpinan yang didasarkan pada efektifitas dan efisiensi dalam mengambil keputusan agar menghasilkan keputusan yang baik bagi organisasi secara keseluruhan.

Kabupaten Bone Bolango menurut Unit Organisasi/Nama Dinas/ Nama Badan Dibawah Pejabat Eselon II dan Jenis Kelamin, 2013 Number of Civil Servant in Regional Institution in by Institution under Functionary Echelon II and Sex, 2013. Dalam birokrasi pemerintahan pekerja, dalam hal ini berstatus Pegawai Negeri Sipil (PNS), dilakoni oleh laki-laki dan perempuan. Dalam hal ini partisipasi PNS laki-laki dan perempuan mestinya tidak berbeda dan tidak 
dibedakan. Kemampuan mereka, sebagai insan pekerja, relatif sama. Semua hal di dalam birokrasi dapat dikerjakan bersama. Dalam hal ini tidak ada istilah pekerjaan tertentu hanya dikerjakan oleh laki-laki sedangkan pekerjaan tertentu lainnya dikerjakan oleh perempuan. Meski demikian, saat ditinjau lebih lanjut, keterlibatan perempuan sebagai pengambil keputusan belum bisa terlibilang banyak. Perempuan masih diposisikan sebagai pelaksana program tanpa dilibatkan dalam segi perencanaan maupun evaluasi program.

Sungguhpun faktanya di Kabupaten Bone Bolango tidak boleh ada pembeda PNS laki-laki dan perempuan dalam birokrasi, akan tetapi faktanya diskriminasi secara sengaja ataupun secara tidak disengaja masih kerap berlangsung. Fakta juga menunjukkan, PNS perempuan dari segi tingkat pendidikan, pengalaman, dan keterampilan masih berada di bawah kemampuan laki-laki. Hal itu terjadi disebabkan karena berbagai faktor, antara lain: budaya yang masih mengungkung perempuan sehingga mereka memiliki akses yang terbatas terhadap pendidikan. Demikian pula dengan kemiskinan (tingkat pendapatan) yang menyebabkan akses pendidikan dan pekerjaan oleh keluarga lebih diutamakan untuk laki-laki mengingat adanya kepercayaan atau kebiasaan bahwa laki-laki sebagai pencari nafkah di dalam keluarga.

Gender bukanlah kodrat ataupun ketentuan Tuhan. Karena itu gender berkaitan dengan proses keyakinan bagaimana seharusnya laki-laki dan perempuan berperan dan bertindak sesuai dengan tata nilai yang terstruktur, ketentuan social dan budaya di tempat mereka berada. Dengan kata lain, gender adalah pembedaan antara perempuan dan laki-laki dalam peran, fungsi, hak, perilaku yang dibentuk oleh ketentuan social dan budaya setempat. Selanjutnya untuk mewujudkan kemitra-sejajaran yakni gender dalam bentuk hubungan sosial dan peran laki-laki dan perempuan sebagaimana dikemukakan di atas diperlukan pemberdayaan, khususnya kaum perempuan. Mereka harus diberitahu dan diberi pemahaman melalui serangkaian kegiatan pemberdayaan mengenai hak, kewajiban, peran, dan tanggung jawabnya sebagai anggota keluarga, anggota masyarakat, dan sebagai anak bangsa.

Dalam pembangunan dewasa ini tidak hanya laki-laki di Provinsi Sulawesi, tetapi juga perempuan sebagai penerus nilai-nilai dan normanorma dalam masyarakat, serta sebagai pelaku pembaharuan dituntut untuk berperan aktif dalam kegiatan-kegiatan di masyarakat yang menunjang pembangunan. Untuk dapat menjalankan peranannya sebagai pembaharuan yang berdaya guna dan berhasil guna. Perempuan perlu mengembangkan diri menjadi pemimpin yang tangguh tanpa meninggalkan kodratnya sebagai perempuan serta menjunjung tinggi harkat dan martabatnya.

\subsection{Peranan Perempuan Dalam Pembangunan Bangsa}

Kita menyadari sepenuhnya bahwa pandangan lama yang memarjinalkan kaum perempuan, sesungguhnya masih ada di masyarakat, atau bahkan pada sebagian elit politik di Kabupaten Bone Bolango. Kaum perempuan dipandang sebagai warga kelas dua, sebagai pihak yang hanya punya hak berkiprah di wilayah domestik. Sementara wilayah publik dipandang bukan menjadi hak kaum perempuan. Kaum perempuan dipandang sebagai pihak yang lemah, emosional, tidak dapat menggunakan akal budinya, dan tidak mampu mengembangkan kepemimpinan yang kuat dan efektif. Kaum perempuan 
dipandang tidak akan mampu masuk ke wilayah politik pemerintahan. Karena wilayah ini dipandang sebagai wilayah yang keras, kompleks dan membutuhkan stamina fisik, sehingga sulit bagi kaum perempuan berkiprah dalam politik pemerintahan untuk setara dengan laki-laki di Kabupaten Bone Bolango.

Memang pandangan-pandangan tersebut pada saat ini sudah tidak lagi menjadi dominan, karena ada banyak peristiwa yang memperlihatkan bahwa pandangan-pandangan tersebut tidak sesuai dengan kenyataan. Kita punya banyak pengalaman yang memperlihatkan bahwa kaum perempuan juga memiliki kemampuan yang sama, dan bahkan dalam beberapa kasus, kaum perempuan dapat melahirkan karya yang lebih baik. Kini kaum perempuan makin memperlihatkan kiprah dan jati dirinya, melalui berbagai karya diberbagai bidang. Kita hampir sulit menemukan jenis pekerjaan yang tidak dapat dimasuki oleh kaum perempuan. Dari pekerjaan-pekerjaan rumahan, sampai dengan pekerjaan memimpin negara, telah mampu dikerjakan dengan baik oleh kaum perempuan. Kiprah Ibu $\mathrm{Hj}$. Megawati Soekarnoputri sesungguhnya merupakan teladan yang sangat baik bahwa kaum perempuan sesungguhnya memiliki kekuatan yang sangat luar biasa. Kiprah beberapa tokoh perempuan di Kabupaten Bone Bolango juga ada, baik dalam lingkup birokrasi maupun lingkup politik.

Apa yang kita perlukan adalah suatu proses perubahan pandangan yang bersifat menyeluruh. Pandangan lama harus digantikan dengan pandangan yang baru. Pandangan baru yang dimaksud adalah pandangan yang melihat kaum perempuan adalah manusia yang juga memiliki hak dan kesempatan yang sama. Dengan pandangan baru ini segala bentuk diskriminasi yang membatasi ruang gerak perempuan hendaknya dihapuskan dan digantikan dengan pandangan yang memperluas ruang gerak kaum perempuan. Lebih dari itu, perlu pula dikembangkan suatu pandangan yang menempatkan kaum perempuan tetap sebagai kaum perempuan. Yakni pandangan yang menilai kiprah dan karya perempuan dari sudut perempuan, dan bukan dari sudut yang lain. Sebagai contoh. Dalam menilai kiprah dan model kepemimpinan kaum perempuan dalam panggung politik pemerintahan, hendaknya cara kita menilai, tetaplah menggunakan sudut pandang perempuan, sehingga perempuan tidak didorong merubah jati dirinya. Kaum perempuan tentu memiliki karakter dan gaya yang khas dalam memimpin, sesuai dengan kepribadiannya.

Kiprah kaum perempuan dalam pembangunan sangatlah diperlukan. Selain argumentasi normatif, yang memperlihatkan bahwa kaum perempuan memiliki hak dan kesempatan yang sama, terdapat suatu kenyataan bahwa "beban" yang kini dihadapi oleh kaum perempuan amatlah berat. Kasus angka kematian ibu melahirkan atau masalah akses terhadap layanan kesehatan yang baik, angka buta huruf atau keterbelakangan dalam pendidikan, masalah kemiskinan dan kelangkaan lapangan pekerjaan bagi perempuan, sampai dengan masalah kekerasan yang kerapkali menimpa kaum perempuan, baik kekerasan dalam rumah tangga ataupun kekerasan lain di luar rumah.

Untuk itulah kaum perempuan hendaknya mengambil peran strategis dalam proses pembangunan, sebagaimana yang dimaksudkan oleh Bung Karno, agar kaum perempuan ikut memastikan arah gerak negara, sehingga kaum perempuan mendapatkan hak dasarnya sebagai manusia yang mulia. Dengan keterlibatan kaum perempuan, maka kepentingan kaum perempuan akan lebih tersalurkan dan lebih dari itu, kebijakan-kebijakan yang muncul akan 
mencerminkan suatu kebijakan yang berorientasi pada kesetaraan dan keadilan gender. Adapun peran strategis yang dapat dijalankan oleh kaum perempuan meliputi:

Pertama, peran untuk ambil bagian dalam merancang suatu model baru pembangunan, yang digerakkan oleh suatu tata kelola pemerintahan yang baik dan adil gender. Kaum perempuan dapat mendorong berkembangnya pandangan baru dan ukuran-ukuran baru, sehingga kiprah kaum perempuan tetap dilihat dalam kacamata perempuan dan bukan kacamata yang bias gender. Kedua, peran untuk ambil bagian dalam proses politik, khususnya proses pengambilan keputusan politik yang dapat berimplikasi pada kehidupan publik. Dalam hal ini, kaum perempuan sudah saatnya membangun keberanian untuk memasuki ranah politik, baik menjadi penggerak partai politik, masuk ke parlemen, atau berjuang melalui posisi kepala daerah. Ketiga, peran untuk ambil bagian dalam proses sosial-ekonomi dan produksi, serta proses kemasyarakatan yang luas. Kaum perempuan dapat menjadi penggerak kebangkitan perekonomian nasional yang lebih berkarakter, yakni perekonomian yang berbasis produksi, bukan konsumsi.

Kaum perempuan sudah saatnya memanfaatkan ruang yang telah terbuka dengan sebaik-baiknya. Beberapa kebijakan yang mulai memperlihatkan suatu kesadaran tentang kesetaraan dan keadilan gender, tentu perlu diperluas dan pada gilirannya arah dan seluruh gerak negara, berorientasi pada usaha membangun tata kehidupan yang setara dan berkeadilan. Kita percaya bahwa hal ini sangat mungkin diwujudkan, sepanjang kita setia pada cita-cita proklamasi kemerdekaan dan ideologi bangsa, yakni Pancasila. Dengan berjalan di atas garis ideologi dan cita-cita proklamasi, kita percaya bahwa tata hidup yang setara dan berkeadilan, akan dapat diraih dengan gemilang.

Manusia dari waktu ke waktu terus berkembang mengikuti arus zaman yang semakin maju. Hal ini diikuti pula dengan berkembangnya budaya yang semakin beragam baik dari segi cara berpakaian maupun cara bersikap. Pergaulan dalam kehidupan sehari-hari serta cara berpikirpun sudah menampakkan garis perbedaan yang tinggi. Perubahan yang drastis ini juga mengakibatkan terkikisnya budaya yang menjadi pondasi moral bangsa indonesia. Siapakah yang harus bertanggung jawab akan merosotnya budaya dan moral pemuda indonesia?. Saat ini peran wanita perlu dipertanyakan, di manakah mereka sekarang dan bagaimana mereka mempertanggungjawabkan posisi mereka sebagai guru pertama bagi anak cucu mereka. Yang mana mereka akan mewarisi dan menempati negeri ini.

Perempuan memiliki peranan yang sangat penting dalam pembangunan masayarakat yang bermoral. Akan tetapi kerap kali peran perempuan menjadi perdebatan. Banyak kalangan yang menilai perempuan seharusnya mendapatkan peran yang lebih didalam kehidupan bermasyarakat. Terutama dalam pendidikan, perempuan merupakan guru pertama bagi anak-anaknya. Dimana anak-anak ini merupakan bibit-bibit penerus bangsa indonesia. Sebagaimana yang dikatakan oleh Syauqi "Ibu ibarat madrasah, jika kau persiapkan maka sesungguhnya anda sedang menyiapkan bangsa (besar) yang wangi keringatnya. Namun, tidak sedikit yang memandang bahwa ranah kerja wanita hanya sebatas dalam kehidupan rumah tangga saja.

Perempuan memiliki peran amat besar dalam kehidupan bermasyarakat dan bernegara. Tanpanya, kehidupan tidak akan berjalan semestinya, sebab ia 
adalah pencetak generasi baru. Sekiranya di muka bumi ini hanya dihuni oleh laki-laki, kehidupan mungkin sudah terhenti beribu-ribu abad yang lalu. Oleh sebab itu, wanita tidak bisa diremehkan dan diabaikan, karena dibalik semua keberhasilan dan kontinuitas kehidupan, di situ ada wanita. Sebagimana yang dijelaskan di atas bahwasanya wanita amatlah penting bagi kehidupan bermasyarakat. Wanita juga memiliki hak yang sama dengan laki-laki. Hal ini juga didukung dengan adanya sasaran peningkatan peranan wanita dalam Repelita VI yaitu dengan meningkatkan taraf pendidikan wanita. Dengan adanya hal ini diharapkan mampu mendukung upaya mempertinggi harkat dan martabat wanita serta makin mantapnya organisasi wanita dan makin aktif peranannya dalam pembangunan.

Begitu besar peran dan pentingnya wanita dalam penbentukan pondasi budaya yang bermoral bagi penerus bangsa. Namun, kenyataan yang ada berbanding terbalik dengan realita yang sesungguhnya. Pada zaman yang semakin maju ini banyak penyalahguanaan kebebasan yang telah diberikan. Kebebasan yang seharusnya digunakan untuk meningkatkan moral bangsa. Namun, hal tersebut menjadi bumerang yang membuat runtuhnnya budayabudaya bangsa ini.

Dalam kehidupan sehari-hari kegiatan pendidikan seperti organisasi dijadikan tameng untuk menutupi kebobrokan prilaku mereka. Misalnya rapat yang hingga larut malam, keluar pada waktu malam hari dengan alasan untuk mengerjakan tugas, berboncengan dengan lawan jenis dengan alasan yang bermacam-macam dan banyak prilaku lain yang telah menyimpang dari aturan yang ada. Cara berpakaian para wanita pada zaman era globalisasi ini juga sudah tidak layak untuk dipandang. Misalnya menggunakan rok yang hanya sampai lutut saja, sehingga sebagian kakinya masih terlihat. Meskipun tidak sedikit yang telah membungkus seluruh tubuhnya dengan gamis, tetapi modelmodel pakaian itu tetap memperlihatkan lekuk tubuh mereka.

Gaya hidup para wanita telah mengikuti gaya barat yang sebenarnya malah merusak moral bangsa. Aturan yang mengikat wanita baik dari segi pakaian maupun tingkah laku telah disubstitusi oleh beragamnya kebebasan yang tak mempunyai batas. Hal ini amatlah terlihat jelas dengan fakta-fakta yang ada. Dahulu para wanita memperhatikan betul adat istiadat yang mereka miliki. Dengan beralihnya perhatian mereka pada perkembangan zaman menjadikan mereka lupa dan acuh tak acuh dengan beragamnya budaya, adat istiadat dan norma yang ada di negeri ini.

Tidak ada minat bagi generasi bangsa tersebut untuk memepelajari dan mempertahankan kebudayaan mereka. Apalagi untuk melestarikan kebudayaan tersebut. Hal ini sangat mustahil karena rasa kebanggaan akan budaya daerahnya sendiri mulai pudar oleh kebudayaan yang bebas. Namun, setelah hal buruk melanda maka kesadaran yang dimiliki barulah muncul ke dasar permukaan. Misalnya terjadi tindak asusila seperti pemerkosaan, hamil diluar nikah, anak tanpa ayah dan lain sebagainya. Selain minat untuk menjunjung nilai norma yang ada, minat untuk mengajarkan ke generasi selanjutnya juga semakin luntur bahkan punah. Oleh karena itu, siapa lagi kalu bukan kita para wanita yang mengajarkan kepada generasi penerus bangsa untuk mencintai negeri yang sudah tua ini. Kita para wanita yang merupakan guru pertama yang seharusnya mengajarkan norma, budaya, prilaku yang bermoral bagi penmimpin-pemimpin negeri yang akan datang. Karena kita yang mempunyai 
banyak kesempatan untuk membentuk pribadi anak cucu kita supaya lebih baik.

\section{PENUTUP}

\subsection{Kesimpulan}

Adapun kesimpulan dalam kajaian tentang penguatan gender dalam pengambilan keputusan birokrasi di Kabupaten Bone Bolango, yaitu:

1. Selama ini keberadaan perempuan sangat dikesampingkan sekali. Geraknya tidak pernah dijadikan perhatian, namun ketika semua orang mengetahui potensi besarnya perempuan merupakan pusat hal yang diperhatikan. Kemajuan peran perempuan di dalam kepemimpinan di Indonesia sungguh luar biasa. Keinginan para perempuan untuk mendapatkan jatah lebih besar di dalam kancah politik pun akhirnya terakomodasi. Ini dapat dilihat dengan adanya kuota 30\% untuk pengurus parpol dan pencalonan anggota legislatif. Gejala ini tentunya berdampak pada tuntutan. Perempuan harus memainkan perannya dalam mewujudkan demokrasi yang tidak bias gender sekaligus sebagai bukti kedewasaan suatu bangsa.

2. Hadirnya sosok perempuan ke kancah dimensi publik baik itu orang nomor satu di Indonesia dan di daerah-daerah membawa kecenderungan baru dalam konteks kekinian. Perempuan ingin dunia memperlakukan kaumnya secara proporsional. Kecenderungan inilah yang salah satunya berimplikasi pada terstimulusnya kaum perempuan bersaing dengan kaum laki-laki untuk menjadi pemimpin. Tentu sangat mudah melakukan inventarisasi ketokohan perempuan di Indonesia. Misalnya bisa dicari dari sisi profesionalitas, intelektualitas, integritas, kemampuan kepemimpinan, dan tentu saja track record-nya di dalam mengurus organisasi atau bidang tertentu.

\subsection{Saran}

Dalam kajian ini masih banyak kekurangan dan kelemahan dalam proses penguatan gender dalam pengambilan keputusan birokrasi di Kabupaten Bone Bolango. Oleh karena itu kajian ini memberikan rekomendasi sebagai berikut:

1. Diperlukan suatu pendidikan, peltihan, work shop dan seminar tentang peningkatan keterlibatan perempuan dalam proses pengambilan keputusan di Kabupaten Bone Bolango. Upaya itu dilakukan melalui suatu kerja sama antara pemerintah daerah Kabupaten Bone Bolango dengan lembaga yang memiliki kompetensi dalam meningkatkan kemampuan perempuan dalam proses pembuatan kebijakan publik.

2. Pemerintah Daerah Kabupaten Bone Bolango perlu mengatur dan mendorong dengan baik perempuan berperan dalam pembangunan di Kabupaten Bone Bolango. Pembangunan tersebut bisa dilakukan melalui pembangunan kemampuan perempuan dalam pengambilan di birokrasi, maupun kemampuan perempuan di bidang politik.

\section{DAFTAR PUSTAKA}

Arifin, lndar. 2010. Birokrasi Pemerintahan dan Perubahan Sosial Politik. Makassar: Pustaka Refleksi

Atmosudirjo.2008. Pengambilan Keputusan. Jakarta: Pustaka Utama. 
Agusnawati (2006). Peran Kaum Perempuan dalam Pengambilan Keputusan pada Masyarakat Pengelola Hutan Kemiri di Mario Pulana Kabupaten Maros. Dalam “Governance Brief” Nomor 28 Juni 2006. CIFOR. Bogor.

Budi, H. S. (1988). Kapulaga. Yogyakarta: Penerbit Kanisius.

Desmita. 2008. Psikologi Perkembangan. Bandung: Remaja Rosdakarya.

Ibnu, syamsi,. 2008. Pengambilan Keputusan dan Sistem Informasi; Jakarta: Bumi Aksara

Karram, Azza (2003) "Partisipasi Politik Perempuan : Tinjauan Strategi dan Kecenderungan, dalam Partisipasi Politik Perempuan dan Tata Pemerintahan yang Baik : Tantangan Abad 21, Jakarta : UNDP

Manar, Dzunuwanus Ghulam (2010) "Perempuan Di Ranah Politik: Ancaman Atau Peluang”, Dalam OPINI FISIP UNDIP Edisi 36/I/2010 (Hal. 01-05)

Mehra, Rekha and Gupta Geet Rao (2006), Gender Mainstreaming: Making it Happen, ICRW

Muchtar, Adinda Tenriangke dkk. (2011), Partisipasi Perempuan Dalam Pengambilan Keputusan di Tingkat Kecamatan dan Desa Di Wilayah Pesisir Sulawesi Selatan, Indonesia, The Indonesian Institute \& Oxfam GB Makassar

Novrizal, Mohammad (2008), Panduan Kerja Parlemen (DPD-RI) dan UNDP Indonesia, Jakarta

Norman K. and Yvonna S. Lincoln. (2003). Handbook of Qualitative. Research. Thousand Oaks, California.

Ollenburger. Jane C., Helen A. Moore, 2002. Sosiologi Wanita, Jakarta: Rineka

Cipta.

Octaviani, Indry., Sri Wiyanti Eddyono, Loly Suhenty, Yenny Widjaya, Risma Umar, Fitriani, Hajar, Sri Rezeky, Wahidah Rustam. 2008. "Inisiatif Pemberdayaan dan Partisipasi Politik Perempuan". Dalam Hodijah, Siti Murwati (Ed.). 2008. Inisiatif Pemberdayaan Perempuan. Studi kasus di Cianjur, Yogyakarta, Malang, Padang Pariaman, Solok, Donggala, Bulukumba. Yogyakarta: Semarak Cerlang Nusa (SCN CREST). $\quad 15$

Parawansa, Indar Khofifah (2009) Meningkatkan Partisipasi Politik Perem_ ${ }^{15}$ li Indonesia, Jakarta

Pierson (2002) dalam Munggoro, Dani. 2010, Teori Eksklusi Sosial, diakses pada 23 September 2013, Buku, E-book, Jurnal, dan Working Paper Adisasmita, Sakti A.

Przeworski, Adam. (1993). Sejumlah Masalah dalam Studi Transisi Demokrasi;dalamO'Donnel, et.al.,Transisi Menuju Demokrasi, Tinjauan Berbagai Perspektif. Jakarta : LP3ES

Reason, James. 1990. Human Eror. Ashgate. ISBN I-84014-104-2

Seda, Fransisia SSE (2003) "Memperkuat Partisipasi Politik Perempuan : Bukan Jumlah Semata", dalam Laporan Konferensi : Memperkuat Partisipasi Politik Perempuan di Indonesia, Jakarta : International IDEA.

Sondang P. Siagian, 2008, Manajemen Sumber Daya Manusia, Bumi Aksara, Jakarta

Soerjono Soekanto, 1996, Sosiologi Suatu Pengantar, Jakarta : PT. Raja Grafindo Persada

Soetjipto, Ani Widyani (2005) "Perempuan "Teraniaya" di Partai Politik" dalam Politik Perempuan Bukan Gerhana, Jakarta : Penerbit Buku Kompas 
(2003) "Meningkatkan Partisipasi Politik Perempuan melalui Reformasi Konstitusi dan Pemilu di Indonesia" dalam Laporan Konferensi :Memperkuat Partisipasi Politik Perempuan di Indonesia, Jakarta : International IDEA

Sudirman, Wiliam, D. and Herlina, N., 2005. Local Policy-making Mechanisms: Processes,Implementation and Impacts of the Decentalized Forest Management System in Tanjung Jabung Barat District, Jambi. Center for International Forestry Research, Bogor, Indonesia.

Subiantoro, Eko Bambang (2004) "Keterwakilan Perempuan Dalam Politik : Masih menjadi Kabar Burung" dalam Politik dan Keterwakilan Perempuan, Jurnal Perempuan (YJP) No. 34. Hal. 69-81.

Sugiyono. (2005). Memahami Penelitian Kualitatif. Bandung: ALFABET.

Sulistyo Hermawan, (2002) Politik Kepemiluan di Indonesia: Jalan Berliku Menuju Demokrasi di Indonesia in A. Croissant, G. Bruns \& M. John (eds) Electoral Politics in Southeast \& East Asia, Singapore: Friedrich Ebert Stiftung 